回回回回回

PHILOLOGIA CLASSICA
DE PHILOLOGIS

ET PHILOLOGIA
回|⿴囗口回回回

VOL. 11 · FASC. 1. 2016

UDC $821.124+811.1$

\title{
A SEMI-SACRED MONSTER: CHARLES WORDSWORTH'S GRAECAE GRAMMATICAE RUDIMENTA (1839)
}

\section{Christopher Stray}

Swansea University, Department of History and Classics

James Callaghan Building, Singleton Park, Swansea, SA2 8PP, Wales, UK; c.a.stray@swansea.ac.uk

Wordsworth's school grammar was the market leader in Britain for several decades. Despite its central position in British education it was unusual, written in Latin at a time when English was becoming more common. The book formed part of an eccentric campaign by the author and his brother to provide standard grammars so as to promote uniformity in religion. Eventually a short English version was produced, and this stopped sales of the original book. The paper traces the interaction between ideology, the politics of education and the economics of publishing.

Keywords: Grammar, Greek, religion, economics of publishing, politics of education, John Murray, Oxford University press, stereotyping.

In his Informal History of Oxford University Press, Peter Sutcliffe pointed to two books as constituting the mainstay of the Press's academic publishing in the mid-nineteenth century: Liddell and Scott's Greek-English Lexicon (1843), and Charles Wordsworth's Graecae Grammaticae Rudimenta (1844). In Sutcliffe's words, 'These two books transformed the business of the Learned Press, reluctant though it was at first to draw any conclusions from their great success' ${ }^{1}$. The Lexicon was and remains an influential and successful book: both it and its offshoots the Abridged (1843) and the Intermediate (1889) are still in print, the latter in its original form. The large lexicon went into eight editions in the nineteenth century, and was again revised in the twentieth ( $9^{\text {th }}$ edition, in fascicle $1925-1940$, in two volumes 1940); a tenth edition, incorporating the supplements of 1968 and 1996, is being prepared for online publication ${ }^{2}$. Wordsworth's Greek grammar, on the other hand, though a market leader in the 1850s and 1860s, reached its final edition in 1882 and is now forgotten. The two books need to be taken together, however, not just because of

${ }^{1}$ Sutcliffe 1978, 12. Sutcliffe had doubtless read the comment of R.W. Chapman in his 'Records of the Press' (OUP archive: 4 copies printed, 1939), 21: 'The Delegates' first really successful schoolbooks were I suppose the abridged Liddell and Scott and Wordsworth's Greek Grammar.' The abridged (school) edition of Liddell and Scott's lexicon was published a few months after the large lexicon in 1843.

${ }^{2}$ For the history of the Lexicon, see Stray 2010.

(C) St. Petersburg State University, 2016 
their shared link with OUP, but because of their striking similarities and differences; and so I begin by considering them as a pair ${ }^{3}$.

The two books appear together in the minutes of the Delegates of the Clarendon Press for 29 March $1844^{4}$. At this meeting the Delegates ordered a second edition of Liddell and Scott to be printed in 6000 copies and accepted Charles Wordsworth's offer of his Grammaticae Graecae Rudimenta. The two books had much in common: both were reference books, both drew heavily on German scholarship, both generated smaller versions of themselves, both dealt with Greek, and both originated with other publishers. Their differences were also significant, however: the lexicon was large and expensive (a quarto volume of about 1600 pages, at 2 guineas), the grammar small and cheap (12 mo, $120 \mathrm{pp}, 3 \mathrm{~s})$. Further, as their titles indicate, the Lexicon was written in English, the Grammar in Latin.

The issue of size and cost was important GR $\nRightarrow C A$ GRAMMATIC $\nexists$ RUDIMENTA.

IN USUM SCHOLARUM.

Editio Quarta.

LONDINI:

APUD JOANNEM MURRAY.

MDCCCXLI. both for the Press and for its authors; the Lexicon was the subject of continual revision till it reached its sixth edition in 1882 , intended at that point to be the final edition, but then there were two more editions before Liddell's death in 1898. The continual revision and reprinting occupied a great deal of time and labour for both editors and Press.

An expensive book which sold in large numbers, as the Lexicon did, was very profitable for its author or (in this case) editors, and despite sharing profits both Liddell and Scott received a substantial income, including payments for both editorial work and seeing the book through the press, as well as a third each of net profits on sales.

The issue of language was one with several ramifications. In the eighteenth century Latin had been firmly embedded as the standard language for classical editions, and most grammars of both Latin and Greek were written in Latin. This began to change in the early nineteenth century, partly because of a more general growth of vernacular publishing, partly because of the prestige of German scholarly books 5 . From the 1780s onwards, German Greek lexica tended to be written in German rather than in Latin. Liddell and Scott thus belonged to a recent trend in using English, though the preface to their first edition was nuanced in its justifications: they thought that English was best for lexical

3 The two books are considered in the context of OUP's classical publishing in Stray 2013a, 450-451, 458-459. As will appear below, Liddell played a role in the making of Wordsworth's Grammar.

4 The Delegates were senior academics who controlled the Press. The role still exists, though sidelined by a modern management structure.

${ }^{5}$ A running battle between the supporters of accessible English and of scholarly Latin had been going on for several decades, fuelled in part by the opening up of a populist market in the early nineteenth century, catered for by E. H. Barker, T. W. C. Edwards, James Hamilton, John Taylor and others: see Stray 1998, 96-102. 
glossing, but Latin for critical notes in editions (and French for mathematics). Wordsworth's grammar was unusual, and its author obdurate, in retaining a Latin text up to its final edition in 1882; as we shall see, this was due not to views on pedagogical convenience, but to a wide-ranging ideological agenda.

The Lexicon had been commissioned in 1836 by the Oxford bookseller and publisher David Talboys, and transferred to the Clarendon Press after his death in May 1840. The Grammar was first published in 1839 by the London firm of John Murray, but was taken to Oxford by its author, as we have seen, in 1844. It is a striking sign of the Delegates' lack of interest in such books that they both landed on their table as a result of external initiative. The Press's failure, in Sutcliffe's words, to 'draw any conclusions' from their success lasted until 1863, when the sacking of Joseph Parker as warehouseman, the hiring of Alexander Macmillan as publisher and the setting up of a School Books Committee initiated an expansion into educational publishing ${ }^{6}$. Both books, then, have histories which fall into two parts. But whereas the Talboys era of the Lexicon (1836-1840) is almost entirely undocumented, the Murray era of the Grammar (1839-1844) is not; in what follows, I draw on evidence from the John Murray Archive, now at the National Library of Scotland, and from the Oxford University Press archive ${ }^{7}$.

\section{The Grammar at John Murray, 1839-1844}

Charles Wordsworth and his brother Christopher were the sons of Christopher Wordsworth, Master of Trinity College Cambridge 1820-1841, and thus nephews of the poet William Wordsworth. Charles went to Oxford, Christopher to Cambridge; they thus gained a broader perspective than usual on the state of contemporary education and scholarship. Charles became second master of Winchester College in 1835, Christopher was appointed headmaster of Harrow School in the following year. They thus had reason to hope for support from public-school headmasters for the campaign for standard grammars which they mounted in 1836.

As the public school community expanded in the 1830 s and preparatory schools were founded, the need for such books became apparent: small boys often moved to a different book every time they changed school, and the differences of doctrine were often considerable. In 1840 Roundell Palmer, reviewing thirteen school Greek grammars, took as an example the noun $\pi \dot{\varepsilon} \lambda \varepsilon \kappa v \varsigma$ and pointed out that 'At Charterhouse and King's College it is classified in the third declension, at Westminster in the fourth, at Bromsgrove in the fifth, at Winchester in the seventh, and at Eton in the eighth declension' (Palmer, 1840, 298). In 1835 Thomas Arnold of Rugby had urged the importance of having standard grammars written, but without success ${ }^{8}$.

${ }^{6}$ The Clarendon Press Series, in reality an imprint rather than a series, began in 1865 and petered out in the 1900s: see Stray 2013b.

7 I am grateful for the kind hospitality of John and Virginia Murray at the archive's original home, 50 Albemarle St, London, over many years, and more recently for the generous assistance of David McClay at the John Murray Archive, National Library of Scotland. My rummagings in catalogued and uncatalogued material in the OUP archive have been greatly helped by Katharine Davis, Beverly Hunt and Martin Maw. Robin Myers made helpful editorial suggestions on an earlier version of the text.

8 Arnold urged the writing of 'national grammars' on Edward Hawtrey, headmaster of Eton: see his letter to Charles Longley, 28 January 1835, in Stanley 1904, 346. At this point Longley was headmaster of Harrow School; he later became Archbishop of Canterbury. 
It was this task that Charles and Christopher took upon themselves in the following year, by writing Latin and Greek grammars on parallel lines, uniform in presentation and typography and mutually supporting 9 .

Their plan was to use Latin for all the explanatory material; a practice which in the 1830s still commanded majority support among academics and schoolmasters. Christopher wrote to Charles in 1836, when they were planning their books, 'The more I see of boys and Grammars, the more I am convinced that a bad Grammar written in Latin is infinitely better for them than a good one written in English' (Wordsworth, 1891, 183). Charles was a keen student of comparative philology and well aware of the advances made in the subject by recent German authors, but in pursuit of his conservative campaign, chose to go back to earlier grammars and to build on them ${ }^{10}$. Both brothers were keen to avoid having their names publicised as authors, something they thought would detract from the authority of antiquity; at one point Christopher asked Murray to bring a halt to printed references to 'Wordsworth's Latin Grammar'11.

The Wordsworths' campaign was aimed at the pragmatic difficulties highlighted by Arnold and Palmer, but it also had a powerful religious dimension. They had both been brought up as high tories and Anglicans, and in the 1830s, when liberalism and reform were in the air, were concerned to bolster established religion and conservative morality. As scholars, they felt that classical literature should be used to defend revealed religion; as schoolmasters, that uniformity in grammar led to uniformity in religion ${ }^{12}$. Both later became Anglican bishops (Charles at St Andrews, 1852-1892, Christopher at Lincoln, 1869-1885), both vigorously refought the religious battles of the late Roman Empire and the Reformation. Their isolation was heightened when their erstwhile ally Gladstone went over to liberal policies in the late 1840s. In 1847, Charles Wordsworth wrote to J. R. Hope, 'WEG has let us down, abandoned the high ground and the sure ground, the mission to save Church and State, and went on to urge uniformity in religion in Britain. D. C. Lathbury commented on this statement, "Wordsworth was left in the fortress raised by his own imagination, secure, had he but known it, in the fact that it would never again be thought worthy of a serious attack ${ }^{13}$. Given their educational and religious views, it was understandable that the brothers turned to the conservative firm of John Murray for publication

9 Wordsworth 1891, 177-200 ('Reform in Greek grammar'). This drew on his 56-page pamphlet The School Greek Grammar (Wordsworth 1866), which includes some details omitted in the later book, though it shares its naïve and engaging prolixity. Christopher explicitly urged the need for a 'national Greek grammar' on Murray in a letter of 9 March 1840. National Library of Scotland, MS.41303, f. 72. In a later letter, he stressed that 'The object will be that the Greek \& Latin Grammars should mutually support each other: $\&$ their typographical execution should therefore correspond as much as possible'. Letter to Murray, 26 June 1841. NLS, MS. 41303, ff. 93-94.

${ }_{10}$ His preface makes this plain: he chose ancient authority and simplicity for a school book, rather than subtlety and complication. Thus Oswyn Murray's description of Liddell and Scott and Wordsworth's book as both 'explicitly based on German models' (Murray 1997, 521), while true for the former, is less so for the latter.

11 Wordsworth to Murray, 27 April 1842. NLS, MS. 41303, f. 95. - He enclosed the offending reference, presumably an advertisement of Murray's.

12 In his Annals (Wordsworth 1891, 186-187), Charles quotes approvingly his brother's declaration that 'uniformity in grammar is no inconsiderable step towards uniformity in religion' (italics in original). Christopher's statement comes from a review of Greek grammars designed to plug Charles's book; it was printed in proof for the Quarterly Review of October 1840, but suppressed to avoid offending Eton.

${ }_{13}$ Lathbury, 1910, I: 372-373. Cf. the comments of the Harrow School master Edward Bowen in his contribution to F. W. Farrar's Essays on a Liberal Education: Bowen 1867, 182-183. 


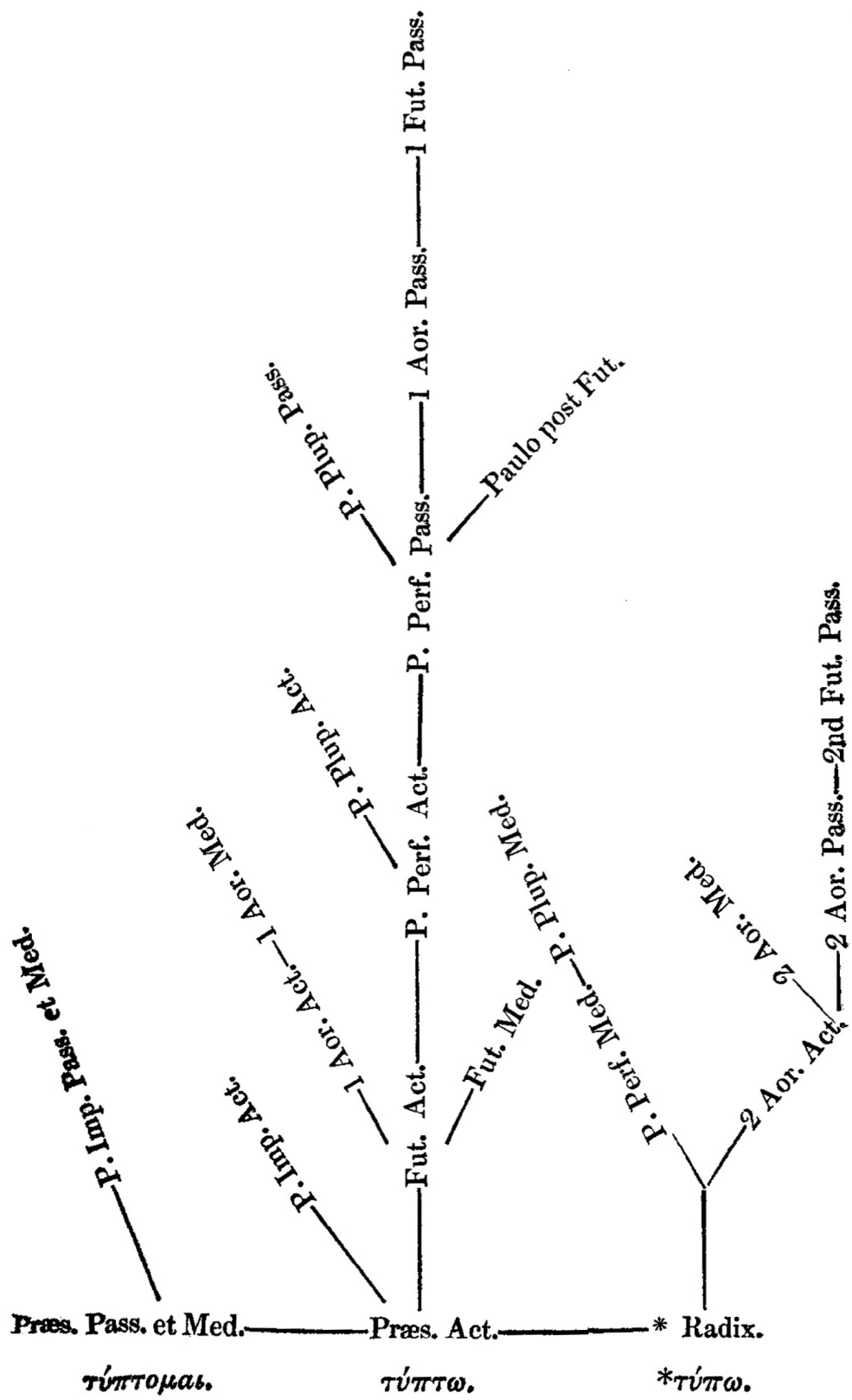

of the books. Charles's accidence was published in 1839, though his syntax, as we shall see, did not follow till 1843. After its publication in 1841 Christopher's Latinae Grammaticae Rudimenta (whose title page was headed King Edward the Sixth's Latin Grammar) was adopted by several leading public schools, and had reached a nineteenth edition in 1866 when its sales 'almost suddenly collapsed' after the publication in September that year of Benjamin Kennedy's Public School Latin Primer ${ }^{14}$.

${ }^{14}$ Wordsworth, 1899, 168. - The book was not reprinted after this edition. 
Charles Wordsworth was a difficult author to work with: he wanted to get all the details right. This extended not just to resistance to stereotyping, but to also to the fine details of type size and binding colour. On 9 February 1839, while the book was being set up, he emphasised to Murray that

'the success of the Grammar will depend in great measure upon the propriety of the experiment involved in the adoption of a smaller type - containing the matter to be reviewed for the second time of going over and required to be clearly and strikingly distinguishable from the larger, but still as it is to be learnt by heart, not too small to be used with ease and certainty'.

In the same letter he regrets that he will give an unusual degree of trouble in the printing of the grammar - 'knowing how much depends on the satisfaction of the eye in matters of this kind' ${ }^{15}$. One of the results of his concern for detail was that his profits were eroded by large printer's bills for revisions and corrections ${ }^{16}$. His insistence on the use of Latin extended even to advertisements; on 27 April 1838, sending Murray his preferred form of words, he had explained that 'As the work is in Latin, I conclude the Advertisement should be so too ${ }^{17}$. His concern with improvement and revision was such that he was willing to abandon copies of one edition bought in bulk for Winchester, in order to accelerate printing of its successor ${ }^{18}$.

Murray took the risks of publishing the first edition himself, sharing profits with Wordsworth, but in 1840 he offered to take a smaller share of them in future editions ${ }^{19}$. The book was printed by Richard Taylor of Red Lion Court, who had previously printed E.V.Blomfield's translation of A.H. Matthiae's Greek grammar for Murray, and was known for his skill in Greek printing, though Wordsworth sent Taylor's specimens to the Clarendon Press, presumably to see if they could do a better or cheaper job ${ }^{20}$. An error which especially irked Charles was of his own making. In revising his Latin preface, he had forgotten to change a word. QUA should have become QUI but he failed to notice it; and then Taylor failed to correct it after being instructed to do so. This was a source of great embarrassment to Wordsworth, since his Latin style was on display; and as he told Murray on 13 February 1839, 'this was particularly awkward from its occurring in a sentence where I profess to have purged the grammar of its former errors ${ }^{21}$.

Wordsworth also had troubles in Winchester. He instructed William Robbins, the College bookseller, to order 200 copies of his book from Murray, but was dismayed to

${ }^{15}$ NLS, MS. 41302, f.10. - The printing history of the Grammar and of its abridged version the Greek Primer (1871) is given in the table at the end of the text of this article, page 113-114 below.

16 The book, which sold at $3 \mathrm{~s} .6 \mathrm{~d}$, was produced on a half-profit share basis.

17 NLS, MS. 41302, f. 3.

18 'My brother is quite content to make the sacrifice of the Grammars on hand; and it would be a very great convenience to me to have the new edition soon. Christopher Wordsworth to Murray, 17 March 1840. NLS, MS. 42303, f. 73.

${ }_{19}$ Murray to Christopher Wordsworth, 7 May 1840. NLS, MS. 4191, f. 38. Murray ended by remarking, 'As you would probably be your brother's adviser in this business I conceive there is no impropriety in addressing you on the subject'. This indicates that Murray recognised the common campaign pursued by the brothers, though it may be that Charles had been dilatory in replying and that Murray was using Christopher as a lever.

${ }^{20}$ On Taylor, see Brock and Meadows, 1998, 40. The sending of specimens to OUP is mentioned in Wordsworth's first letter to Murray, of 13 February 1838 (NLS MS. 41302, ff. 1-2). Thomas Gaisford, Dean of Christ Church and a Delegate of OUP, had earlier suggested that his Press should be used.

${ }^{21}$ NLS, MS. 41302, f. 14. 
find that they arrived, as he told Murray on 28 February 1839, 'in puris naturalibus instead of the verdant attire which I had expected ${ }^{22}$. Meanwhile reports of minor errors were coming in, both from his Winchester colleagues and from masters in other schools. Wordsworth had ordered a dozen interleaved copies for supply to such helpful colleagues (including Edward Hawtrey, headmaster of Eton), and in March was fretting both about their non-arrival at Winchester and the apparent lack of Advertisements for the book in the Times and the Publishers Circular ${ }^{23}$. By the following January, however, he was cheered to be told the edition had almost sold out, and was busily planning a second edition, asking Murray which schools had bought the Grammar in large numbers so that he could ask their headmasters for comments. It is striking that in the same letter he proposed a new edition of only 1000 copies, half the size of the first ${ }^{24}$. His brother Christopher, as he himself later told Murray, had advised against a longer print run, arguing that 2000 runs would have a better chance of spreading the book around the leading schools, and would also give more opportunity for revisions based on comments from schoolmasters ${ }^{25}$. Murray warned that such a short run would be unprofitable for him, and Wordsworth agreed to 2000; but he soon asked to revert to 1000 , all costs to be borne by him. In a later letter, however, he suggested that if Taylor would keep the book in standing type for a few months, to enable changes to be made, he would be prepared to have an edition of $5000^{26}$. In August he proposed an abridged edition, to be printed as an experiment in a 500 run, and to consist of the matter printed in larger type in the larger book. This introductory book, the Graecae Grammaticae Rudimenta Minora, duly appeared in 1841; in 1843 it was adopted by Eton for use by the third form, and co-published with the College's bookseller E.P.Williams.

Wordsworth realised that no grammar could be claimed as a standard textbook unless it was accepted by Eton, the leading school in the country, but that Eton would be unlikely to accept a book written elsewhere (Wordsworth 1891, 178). He visited Edward Hawtrey, the then headmaster, to persuade one of his staff to write the book to ensure its adoption there; but nothing came of this. Later, as Charles wrote his grammar, his brother Christopher was busy working on a review of Greek grammars for the Quarterly Review which would in effect be a plug for his brother's book ${ }^{27}$. But in the course of his research, he found that the Eton Greek grammar was in fact an edited version of Camden's written for Westminster several centuries earlier and long superseded. Eton had thus in effect pirated both its grammars - the Latin grammar being an edition of Lily, originally written for St Paul's ${ }^{28}$. In October 1840 two other reviews surveyed the field, praised Wordsworth's book and criticised the Eton grammar severely. One of them, in the Educational Magazine,

${ }_{22}$ NLS, MS. 41302, f. 18. - Evidently Robbins had been sent unbound copies. Soon afterwards, Robbins became bankrupt, and Wordsworth was obliged to pay what Robbins owed to Murray, £40.19s. In 1847, rather belatedly, he asked Murray to share the burden: Wordsworth to Murray, 19 Apr. 1847. NLS, MS 41302, ff. 76-77. According to Murray's copies ledger, Robbins sent 300 copies of the first edition in Feb.1839, and 275 of the $2^{\text {nd }}$ and 200 of the $3^{\text {rd }}$ in Jan.1841. Copies Ledger D. NLS, MS. 42729, f. 243.

${ }^{23}$ Wordsworth to Murray, 17 March 1839. NLS, MS. 41302, ff. 20-21.

${ }^{24}$ Letter of 15 Jan. 1840. NLS, MS. 41302, f. 24-25.

${ }_{25}$ Christopher Wordsworth to Murray, 1 February 1840. NLS, MS. 41303, ff. 67-68.

${ }^{26}$ NLS, MS. 41302, '1840'.

27 The review was first mentioned in a letter to Murray on 18 January; it was welcomed on 31 March by J. G. Lockhart, editor of the Quarterly, and reached corrected proof stage in June.

28 The Latin book had been published in 1758, the Greek grammar in 1768. 
was written by Wordsworth's friend Henry Liddell of Christ Church ${ }^{29}$. The other appeared in the British Critic, and was written by Wordsworth's friend Roundell Palmer (Palmer, 1840). Hawtrey was much offended by these reviews, and after consulting him, J. G. Lockhart, the editor of the Review, who had strong Etonian connections, suppressed the article, which was printed up ready for publication in the same month ${ }^{30}$. Hawtrey's awareness of his own inferior classical scholarship made him all the more unwilling to take advice. As a result, grammatical anarchy reigned within Eton, as the following sketch of Hawtrey by his junior colleague William Johnson (later Cory) makes clear:

'He made a vehement effort to restore the tyranny of the Eton Greek
Grammar, but he could not force a set of young men [i. e. his assistant
masters] back into the old routine... in due time even Hawtrey, the last
hereditary champion of the Eton formula, acquiesced in the existence at
Eton of masters who could not go through the list of twenty-two kinds of
verbs which govern a genitive... It was an awkward and indecorous thing
that his young colleagues, who had cast off the Eton yoke and learned true
Greek at Cambridge from Shrewsbury men, should be charged with the
training of boys by parents who expressly said that they knew Dr Hawtrey
to be an unsound scholar. In the teaching of Greek, in less degree of Latin
also, Eton for many years presented the curious phenomenon of moderate
anarchy....the introduction of a few changes in the old accidence, the
binding in one volume of the Eton accidence and the accurate but painful
syntax composed by Mr Wordsworth... the engrafting of Dr Kennedy's
elegant syntax on the reformed accidence, and attempts at private
manuscript grammars, based on Kuhner, are some of the many signs of
discord and confusion...

Christopher's book was offered to Murray and accepted in 1841; it reached a sixth edition in 1849, and was the market leader in its field until Kennedy's Public School Latin Primer appeared in 1866. He and his book stayed with Murray throughout, and in 1844 he agreed to have it stereotyped, 'for the next edition but one', since 'I ... have now made the book as perfect as I can $^{32}$. Charles was determined to have his book used at Eton, since a book used there would be adopted at many other schools. No wonder he was, as he told Murray on 27 November 1843, 'desirous to meet his [Hawtrey's] wishes even beyond what is reasonable ${ }^{33}$. First he tried to have the Grammar printed at Eton by Williams, the school bookseller, but that fell through. Then Hawtrey told him that Eton would accept the book if it was published by one of the two university presses, and he immediately wrote to Dean Gaisford to offer it to Oxford University Press, who as we have seen accepted it on 29 March 1844. Wordsworth wrote to Murray on 3 April to inform him of

${ }^{29}$ Liddell, 1840. Liddell tried to be diplomatic ('Little can be done without her [Eton's] aid; with her everything'), but he made it clear that the Eton grammar 'is quite unworthy to prevail as it now does.' Wordsworth only found out about Liddell's authorship after the publication of his Annals in 1891, when Liddell wrote to tell him (Wordsworth, 1893, xxviii).

${ }^{30}$ Christopher Wordsworth kept a copy of the printed proof in his papers, but it has not been located.

${ }^{31}$ Quoted in Lyte, 1899, 409-410. Johnson joined the Eton staff in 1845, and was sacked in 1872.

32 Christopher Wordsworth to Murray, 5 February 1844. NLS, MS. 41303, f. 112.

${ }^{33}$ NLS, MS.41320, f. 48. - Christopher had asked Murray to consider letting the Eton bookseller share in the Latin grammar, but this proved to be impracticable. 
the change, explaining that he was not dissatisfied with Murray, but was acting in a great public cause $^{34}$. John Murray was not pleased:

'Your letter of Apr 3, has caused me, as you may well suppose, no little astonishment. I will not dwell upon the expenditure of time and pains employed during the last 4 years, in endeavouring, and not unsuccessfully I hope to promote the success and circulation of your Greek grammar to the prejudice of my own Book, the abridged Matthiae ${ }^{35}$. Nor will I allude to the utter \& total loss to me of the undertaking in a pecuniary point of view, further than to remind you that this result was occasioned by my entire compliance with your wishes in the mode of bringing out the Book - but I cannot pass over the slur and slight to me professionally as a publisher in thus throwing me overboard, after having 'borne the burthen and toil of the day', at the very moment when the success of your Book appears decided and I was fairly entitled to look for some return different from that which you now hold out to $\mathrm{me}^{36}$.

I cannot doubt that from your own sense of justice you will regard my present position in a light not very different from that in which I have represented it and that having made an arrangement satisfactory to yourself at Oxford you will also under the circumstances take some pains to ensure for me at least the Agency of the Grammar and to secure the appearance on the title page of my name as publisher, a point on which I assure you I lay great stress - as likely to affect me in my business - I hope to hear favourably from you in reply to this...'

\section{In July he was still pursuing Wordsworth:}

'You brought your Grammar to Albemarle Street at a time when it was unknown, and when Mr Murray's name was of some use to it. I continued to publish Edition after Edition, not only with no gain, but with a certainty of loss. The fortune of your book is now made; you will not use me as a stepping ladder, \& now kick me off? If you do, I will venture to say that Author never so treated Bookseller before ${ }^{37}$.

Murray's correspondence with the brothers supports his account. In a letter to Christopher Wordsworth of February 1844, for example, he had pointed out that the need for extensive advertising for a first edition, and the length of the Latin advertisements he sent for printing, had increased the cost of the Grammar; but as the book became established, such costs should drop away. He closed by hoping that a future edition could be stereotyped; but both brothers resisted this, so as to be able to revise their texts ${ }^{38}$. To Charles Wordsworth he wrote that his author's corrections, 'almost unparalleled in so small

${ }^{34}$ NLS, MS. 41302, 69-70. - This letter was misdated to the following year when it was originally filed, but clearly belongs to 1844 .

${ }^{35}$ E. V. Blomfield's translation of August Matthiae's large Greek grammar had been published by Murray in 1818; the abridged version for schools made by his brother C. J.Blomfield had followed in 1822 and reached a fifth edition in 1841 .

36 The quotation is either a deliberate variation on, or a misremembering of, "borne the burden [or burthen] and heat of the day' (Matthew 20:12). The list of editions shows that, as Murray said, the Grammar was taking off as a serious seller.

${ }^{37}$ Murray to Wordsworth, 6 July 1844. NLS, MS. 4191, f. 172.

38 Murray to Christopher Wordsworth, 6 Feb. 1844. NLS, MS. 41911, f. 147. - Later that year Murray pointed out that his previous terms would have to be changed, as Wordsworth's revisions had made his book bigger and thus more expensive to produce: Ibid. f. 158. As we have seen, Christopher was less absolutist than his brother in this respect. 
a work', the small print runs and the long and costly advertisements, were 'like manure on a field: - you are now reaping the fruits \& will continue to do so' ${ }^{39}$.

Wordsworth replied on the $8^{\text {th }}$ that

'What I have done, I have been induced to do solely with a view to effect, as I conceive, a public good: - but this I should never have thought of attempting had I supposed it to be attended with a palpable \& acknowledged private wrong.'

He went on to explain that the advisors he had consulted 'recommended me, some time since, to change my Publisher ${ }^{\prime}{ }^{2}$. Wordsworth tried to secure a place for Murray as London agent for the book, with his name on the title page, but was rebuffed by Gaisford $^{41}$. The correspondence continued over the summer but now focused on two offshoots of the Grammar. The abridgement, Rudimenta Minora, was now put into the joint hands of Murray in London and Parker in Oxford. In the summer of 1843, while on holiday in Switzerland, Wordsworth had finally finished the much-delayed syntax, which he sent to Murray for printing on 6 September ${ }^{42}$. The syntax of the Grammar was printed off separately for use at Eton, Murray in this case sharing with the Eton bookseller E. P. Williams. As William Johnson's account, quoted above, mentioned, this was bound up with the Eton accidence. Wordsworth also suggested other titles to Murray, in part perhaps to give him compensatory business, though they clearly fitted with the brothers' grammatical campaign. In March 1845 he proposed, as companions to the Latin and Greek textbooks, grammars of Hebrew, Italian, Modern Greek and French ${ }^{43}$.

\section{The Grammar at Oxford University Press, 1844-1882}

The book seems to have been put to press in Oxford as soon as it was accepted by the Delegates ${ }^{44}$. It was published on 15 June 1844, priced at $4 \mathrm{~s}$, and Wordsworth was paid $£ 20$ per 1000 copies printed ${ }^{45}$. During its first year with OUP the Grammar was bought in large numbers by both Edward Gardner and Joseph Henry Parker and in relatively modest amounts by Payne \& Foss, Longman and Rivington. The largest orders came from Gard-

39 Murray to Wordsworth, 12 July 1844. NLS, MS. 4191, f. 173.

40 Wordsworth to Murray, 8 July 1844 . NLS, MS. 41302, ff. 63-64.

${ }^{41}$ Wordsworth to Murray, n. d. but probably July 1844 . NLS, MS. 41302, ff. 88-89.

42 Wordsworth to Murray. NLS, Add MS. 41302, ff. 45-46. The holiday had been shared with Henry Liddell, fresh from his labours on the Greek lexicon published by OUP earlier in the year. The first editions ran to pp.xii +200 . The main text of the final $\left(19^{\text {th }}\right)$ edition of 1882 extended to nearly $260 p p$, the syntax being pp. 163-216.

${ }_{43}$ Wordsworth to Murray, 12 Mar. 1845. Inspected at the John Murray archive in 1987 but apparently not now held at NLS. On 25 May 1844, Christopher Wordsworth told Murray that 'references to the Latin will be introduced into the new Edns of the Greek [grammar].' NLS, MS. 41303, f. 128.

$443 \frac{1}{2}$ sheets were printed in the period 26 January-3 May, the rest in the period 3 May-27 October: OUP archive, PR 13/8/1, 'Record of Editions 1791-1862'. In his Annals, Wordsworth claimed that the fifth edition of '1843' bore the Clarendon imprint on its title page (Wordsworth 1891, 192). But he was writing fifty years later.

45 Wordsworth later recalled that Gaisford had made sure the book was published at the lowest possible price - undercutting by a third, he thought, what Murray would have charged for it (Wordsworth, $1866,37)$. The Delegates later raised his fees; for the following edition of 6000 , he was given $£ 170$; in 1848 , for the same print run, and in 1851, for a 5000 run, he received $£ 200$. In 1857, for a 6500 run, payment was increased to $£ 220$. 
ner, the Press partner who ran the London warehouse, and it may have been Gardner's order of an additional 2000 copies in the late summer of 1844 that brought this text to the attention of other booksellers, such as Longman, who bought an additional 250 copies $^{46}$. Longmans also published a book of examination questions on the Grammar ${ }^{47}$. After the 1861 printing the book was kept in standing type, which as Robert Scott explained to Wordsworth, reduced the need to take larger impressions ${ }^{48}$. Wordsworth made respectable sums from the book, but much less than Liddell and Scott did, despite their duality: not only was the large Lexicon an expensive book, its editors also received substantial payments for work on preparing revised editions of this and the abridged lexicon and seeing them through the press. In 1877, for example, Wordsworth was paid $£ 56$ for the Grammar and $£ 65$ for the smaller Primer based on it (about which, more below). In contrast, Liddell and Scott shared $£ 650$ for the full and abridged versions of their lexicon. In 1892, the year of his death, Wordsworth's payments had sunk to less than $£ 30$, of which the Grammar earned a mere $£ 2.19$ s. Liddell received nearly $\mathfrak{E} 190$, Scott having died in $1887^{49}$.

The potential of the public-school market was brought to the Delegates' attention in the early 1860s, just as they were moving into educational publishing. In 1861 a royal commission was set up under the chairmanship of the Earl of Clarendon to investigate the nine leading public schools; its report was published in $1864^{50}$. In 1863 , the year in which Parker was sacked as warehouseman and Macmillan appointed as publisher by OUP, the commissioners recommended to the nine headmasters that they commission standard grammars of Greek and Latin; they asked Benjamin Kennedy (one of their own number) to produce a Latin grammar, and Charles Wordsworth to revise his Greek grammar, for the nine schools ${ }^{51}$. George Kitchin, secretary to the Press's School Books Committee, wrote to Alexander Macmillan on 23 July that 'Mr Wordsworth ... is going to prepare a Primer to correspond to Kennedy's Latin Primer which the 9 Masters have now finally accepted ${ }^{52}$. The prestige of the Clarendon schools meant that other public schools would follow their lead on books. It is a remarkable historical irony that because of the role of the Earl of Clarendon as chairman of the Commission, the Delegates of the Clarendon Press were now confronted with the power of the Clarendon headmasters ${ }^{53}$. The commissioning of standard textbooks thus provided the Press with both opportunities and constraints.

46 Wright's Warehouse Records, OUP archive, PR/13/11/1.

47 Engledow, 1845. - Charles Engledow was Master of the Episcopal School in Haddington, Edinburgh, and so is likely to have been in contact with Wordsworth.

48 Scott to Wordsworth, 14 June 1861. Robert Scott letterbook 1861-1873, OUP archive, C/1/4.

49 OUP archive, Finance Committee minutes, 9 November 1877, 8 December 1892. After Scott's death, his executors repaid $£ 600$ of advances against royalties on the $7^{\text {th }}$ edition of the lexicon: Ibid. 21 Apr. 1888. The three men's wealth at death, as recorded by ODNB, was $£ 58,000$ (Scott), $£ 21,000$ (Wordsworth), and $£ 68,000$ (Liddell).

50 The Commission was in fact aimed at Eton, but this was veiled by the inclusion in its remit of Harrow, Winchester, Shrewsbury, Charterhouse, Westminster, St. Paul's, Rugby and Merchant Taylors. See Shrosbree 1988.

${ }^{51}$ Kennedy was asked to provide both books, but refused to assemble a Greek equivalent, fearing accusations of monopoly. For the story of his Primer, see Stray 1995, an edition of the 36 letters which appeared in the Times after Kennedy's book was published in September 1866, and Stray 1998, 191-198.

52 Kitchin to Macmillan, BL Add MS 55054, f. 1. The nine headmasters had in fact asked Wordsworth to revise his Grammar, and to make an abridgement for younger pupils (a Primer).

${ }^{53}$ The heads were often referred to as 'the Nine Masters', or simply 'the Nine'. Contemporaries thought of the Nine Muses; modern readers may be reminded rather of J.R. R. Tolkien's Nazgul. At the end of 1865, George Kitchin wrote that 'The Committee cannot move till they know more about these 'awful Nine' who 
The positive aspects of this situation were immediately evident in the large print runs of 10,000 in 1867 and 1870 . These brought with them proposals for stereotyping, but Wordsworth rejected them so that he could continue to revise his text ${ }^{54}$. He also refused outright to allow his book to be included in the Press's new Clarendon Press Series of educational books, whose first title had appeared at the end of 1865 . He may have seen the Series as a rival to the series in posse represented by his and his brother's grammars; or perhaps simply disliked the idea of entering a series which might impose its own rules on his own book ${ }^{55}$. Wordsworth was both conservative and stubborn, resisting pressure from the Delegates to translate his book into English, and only reluctantly agreeing to use English for the Greek primer abridged from the larger book. His resistance of course had ideological roots, but he may also have remembered how his brother's Latin grammar, written in Latin, had been displaced by Kennedy's, written in English. The earliest suggestion for a change of language came in 1866, in a letter from Kitchin:

'[The Grammar] will continue to be in Latin, I suppose, in spite of the growing wish for English grammars. Will the Primer also be in Latin? There is, of course, no objection with beginning in English and passing to Latin ${ }^{56}$.

In October 1869 Bartholomew Price, Secretary to the Delegates of the Press, reported to Wordsworth that 'Mr Macmillan is strongly of the opinion that the Greek Primer should be in English only; and that a Latin one would be useless, and indeed harmful. It would interfere with the sale of the larger Grammar, \& could only supply a want which the larger Grammar does sufficiently well ${ }^{57}$. Soon afterwards he put the pressure on, raising the fear of competition between two books both written in Latin:

'The wish of all [the Delegates] is, and in this wish you will no doubt share, that the Primer should not interfere with the sale of the Grammar. The Delegates fear even more strongly than $\mathrm{Mr}$ Macmillan that the issue of the Primer at all will have this effect; and consequently they think that the form of it should be as different as possible from that of the Grammar: and that it should not be in Latin. Were it so, it would certainly be bought for the Junior Classes in the Schools, where the Grammar is now used and the sale of the latter would be thus far diminished. The object of having the primer is to supply a different market to that supplied by the Grammar: there are, it is thought, many Schools below the great Classical Schools where the Grammar is not used, but in which the Greek Primer in English would be used. This is the opinion of Mr Macmillan and the Delegates share in it $^{58}$.

hold in their hands the fatal Grammar of the future'. Kitchin to Revd J. Ridgeway, 30 December 1865. OUP archive, Kitchin letterbook, C/1/5.

${ }^{54}$ The payment was equivalent to $2^{\text {nd }}$ a copy. Such outright payments seem to have been the norm in this period. In 1868 the Press increased Wordsworth's payments by allowing him 2/3 of profits: OUP archive, Finance Committee minutes, 13 December 1868. The only clue to Wordsworth's profits while with Murray is that on 21 February 1842, Murray told him that an edition of 5000 copies of the grammar would produce a profit of about $£ 220$ (NLS, MS 41911, f. 83). On 6 February 1845 Murray offered Christopher Wordsworth 60 guineas for an edition of 3000 of the Latin grammar, or 30 guineas per 1000 if it were stereotyped. NLS MS. 41911, f. 148.

${ }^{55}$ In fact the Series was remarkably diverse (Stray 2013b). The other author who refused to allow his books to go into the Clarendon Press Series was Ingram Bywater, but the issue in this case was one of page format and text layout.

${ }_{56}$ G. W. Kitchin to Wordsworth, 21 February 1866. Kitchin letterbook 1865-6, OUP archive, C/1/5.

57 Price to Wordsworth, 18 October 1869. OUP archive, Secretary's letterbooks.

${ }_{58}$ Price to Wordsworth, 1 November 1869. OUP archive, Secretary's letterbooks. 
A year later, Price sent a copy of the Greek primer to Robert Scott with corrections suggested by several schoolmasters, commenting that 'I thought it best to obtain your opinion previously to sending them to him. He may require some pressure ${ }^{39}$. The new book, published in 1871, was brought out under the imprint of the Clarendon Press Series which Wordsworth had rejected for the larger book. It soon eroded the sales of its larger sibling, whose print runs dropped to 3000 at longer intervals, the final printing being in $1882^{60}$. Looking back in 1891 , Wordsworth told the story of the headmasters' resolution of 1866 , and complained that

'...to judge from the fact that for some years the sale of the Grammar has not been increasing, but rather the contrary, I am afraid it must be inferred that not only has the resolution ... not been faithfully adhered to ... but that, in a word, there has been backsliding.'

And in a regretful footnote, he added that 'A primer, in English, which, against my own judgment, I was prevailed upon to put out in 1870 has greatly tended to check its circulation' (Wordsworth 1891, 190). In 1885 the Delegates, probably stirred to action by reports of a revision of Kennedy's Public School Latin Primer, were dissatisfied enough to consider a plan to publish a new grammar and primer, written together ${ }^{61}$. Nothing seems to have been done, but in the following year the Press's Publishing Committee drew Wordsworth's attention to his declining sales ${ }^{62}$. He had in fact drawn Bartholomew Price's attention to his declining profits at the beginning of 1885, citing combined figures for both books: $£ 117$ in 1879 , falling steadily to $£ 84$ in 1884 . He suggested that an article might be planted in 'some popular magazine', mentioning that the editor of the Fortnightly Review was sympathetic, but Price seems to have persuaded him that this was not worth doing ${ }^{63}$.

William Johnson's reference to Wordsworth's 'accurate but painful syntax', quoted above, is representative of the opinion of many users of the book. Testimony is available from pupils who suffered from it in three successive decades. The late nineteenth-century headmaster of Winchester, William Fearon, who had used the book as a pupil there in the 1850 s, recalled at the age of 85 that it appeared in his dreams, and that he still shuddered at the sight of p.75 (see p. 111)'. He was referring to the section on the Future Middle of verbs, including a list of fifty verbs lacking this form which had to be learned by heart: 'A more preposterous waste of effort, or one more calculated to disgust us with the Greek language, it is difficult to imagine' (Fearon 1936, 48). The educational historian A.F.Leach, another old Wykehamist who used it in the 1860s, called the Grammar 'the ideal of all that is hideous and hateful in learning' (Leach 1899, 464). Another painful section was

59 Price to Scott, 17 October 1870. OUP archive, Secretary's letterbooks. below.

60 The printing history of the Primer is given in the Table at the end of the main text, page 113-114

${ }^{61}$ The problems the Delegates faced with an ageing and reluctant author were mirrored in those Longmans had with their own star grammarian, Benjamin Kennedy; his Public School Latin Primer (1866) was widely unpopular but Kennedy resisted revision, which was eventually carried out by his daughters. See Stray, Classics Transformed, pp. 193-196.

62 OUP archive, Publishing Committee minutes, 11 June 1886. The final printing of the Grammar had been in 1882. The OUP file copy (08/40170) is from this edition, and is 'editio undevicesima, 1882'. The MS printing history it carries, however, calls the 1882 printing ' $20^{\text {th }}$ edition'. Editions (or rather impressions) are only listed individually from the ' $16^{\text {th' }}$, and the evidence is insufficient to resolve the discrepancy; I have found no copies of a $20^{\text {th }}$ edition.

${ }^{63}$ Wordsworth to Price, 1 January 1885. OUP Archive, PUB/11/4. 


\section{Formata a FUTURo.}

\section{§ 56. Futurum Medium.}

\section{Futurum Medium formatur a Futuro Activo, mu-

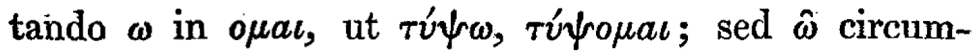 flexum in ôे $\mu a \iota$, ut $\sigma \pi \epsilon \rho \hat{\omega}, \sigma \pi \epsilon \rho o \hat{v} \mu a \iota$.}

Obs. 1. Doribus Futurum Medium semper erat in ov̂ $\mu a \iota$; quo sæpe utebantur etiam reliqui in quibusdam verbis, etsi in Activâ voce non circumflexis; ut $\phi \epsilon \dot{v} \gamma \omega$ fugio, $\phi \epsilon v \xi o \hat{v} \mu a \iota$ et -o $\mu \alpha \iota$. Sic

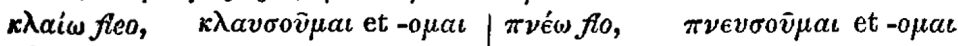

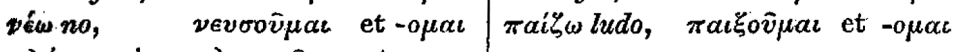
$\pi \lambda \dot{\epsilon} \omega$ ravigo, $\pi \lambda \epsilon v \sigma \sigma \hat{v} \mu a \iota$ et $-o \mu a \imath$

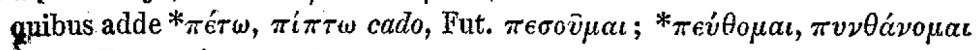
audio, Fut. $\pi \epsilon \dot{v} \sigma o \mu \alpha \iota$ et nonnunquam $\pi \epsilon v \sigma o \bar{v} \mu \alpha t$.

Obs. 2. Duo Verba etiam Mutam Characteristicam habentia, formant

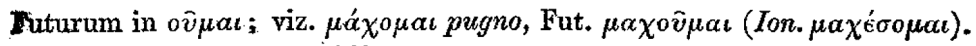

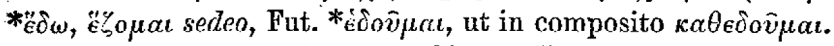

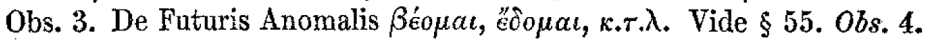

Obs. 4. Multa sunt verba quæ Futuro Activo, apud Atticos certè, carent, et Futurum Medium ejus loco adsciscunt; præsertim ferè omnia in $\zeta \omega$, qux soni emittendi notionem habent; Conf. $\$ 47 .(c)$. 1. ut ákov́w audio, Fut. äxov́ropat, nusquam (nisi apud recentissimos scriptores) ákov́ow.

\begin{tabular}{|c|c|c|c|}
\hline & & & \\
\hline ic $\not \partial \delta \omega$ cano & $\not \ddot{q} \sigma o \mu \alpha t$ & ${ }^{*} \lambda \eta_{\eta}^{\prime} \chi \omega$ sortior & $\lambda \eta^{\prime} \xi о \mu \alpha \iota$ \\
\hline *à $\lambda o ́ \omega$ capio & $\dot{a} \lambda \omega \sigma o \mu \alpha t$ & 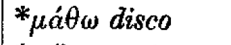 & $\mu \alpha \theta \dot{\eta} \sigma o \mu \alpha \iota$ \\
\hline$\dot{a} \mu \alpha \rho \tau \operatorname{a} \nu \omega$ erro & $\dot{a} \mu \alpha \rho \tau \dot{\eta} \sigma o \mu \alpha \iota$ & $* \mu o ́ \lambda \omega$ verio & $\mu_{0} \lambda_{0} \hat{v} \mu \alpha \iota$ \\
\hline$\omega$ occurro & бopat & $\nu$ éw no & 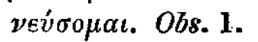 \\
\hline$\alpha v^{\prime} \omega$ fruor & $\dot{\alpha} \pi \circ \lambda \alpha \dot{v} \sigma o \mu \alpha \iota$ & oi $\mu \omega_{\zeta \zeta} \omega$ ploro & ớ $\mu \omega^{\prime} \xi_{0} \mu \alpha t$ \\
\hline & $\beta \eta \dot{\eta} \sigma 0$ & $\not \mu \nu v \mu:$ juro & $\dot{o} \mu o \bar{v} \mu a \iota$ \\
\hline$\beta o a ́$ & $\beta$ ßno & $\pi \alpha i \zeta_{\omega}$ ludo & 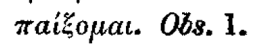 \\
\hline$\gamma \in \lambda$ & $\gamma \in \lambda$ & 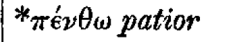 & $\pi \epsilon i \sigma o \mu a \imath$ \\
\hline iesco & $\gamma \eta \rho$ & $* \pi \varepsilon ́ \tau \omega$ cado & $\pi \varepsilon \sigma o \hat{v} \mu a \imath$ \\
\hline io & $\gamma \rho \tilde{u}_{s}^{\xi} \circ \mu \alpha \imath$ & $* \pi i \omega$ & tiopal \\
\hline$* \gamma$ & $\gamma \nu 0$ & $\pi \lambda \operatorname{ć}^{\prime} \omega$ & 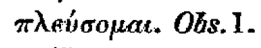 \\
\hline ormio & $\delta \alpha p t$ & $\pi \nu^{\prime} \gamma$ & $\pi v i \xi$ \\
\hline * $\delta a ́$ & $\delta a ́ \sigma$ & $\hat{\rho} \dot{\epsilon} \omega$ & $\dot{\rho} \epsilon \dot{v}$ \\
\hline 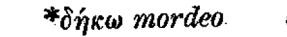 & $\delta \dot{\eta} \xi$ & $\dot{\rho} 0 \phi a ́ \omega$ sorbeo & $\grave{\rho} \circ \phi \dot{\eta} \sigma o \mu \alpha \iota$ \\
\hline ufugio & $\delta \rho \alpha \alpha^{\prime}$ & $\sigma \iota \gamma \alpha \dot{\alpha} \omega$ & $\sigma \iota \gamma \eta \dot{\eta} \sigma 0 \mu \alpha \iota$ \\
\hline * ¿ó & $\delta \rho \alpha_{i}$ & $\sigma \omega \omega \pi$ & $\sigma \iota \omega \pi \dot{\eta} \sigma o \mu \alpha \iota$ \\
\hline admiror & $\theta a v$ & $\sigma \kappa \omega ́ \pi \tau \omega$ cavillor & $\sigma \kappa \omega ́ \psi о \mu a \iota$ \\
\hline$\theta \underline{\varepsilon} \omega$ & $\theta \in u ́ \sigma o \mu a t$ & 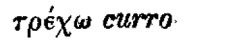 & $\theta \rho \epsilon^{\prime} \xi_{o} \mu a \imath$ \\
\hline marior & $\theta \alpha \nu 0 \bar{v} \mu \alpha t$ & $\tau \rho \omega ́ \gamma \omega$ rodo & 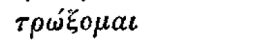 \\
\hline$* 06$ & Gooovินat: & $\phi \epsilon \dot{\gamma} \gamma$ & 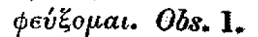 \\
\hline 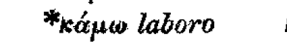 & $\kappa a \mu \rho \bar{\mu} \mu \alpha t$ & $*_{\phi} \theta a ́ \omega$ pravenio & $\phi \theta \dot{\eta} \sigma o \mu \alpha \iota$ \\
\hline & $\kappa \lambda \lambda a v \sigma o \mu \alpha$ & 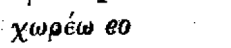 & $\chi \omega \rho \eta \dot{\sigma o} \mu \alpha \iota$ \\
\hline${ }^{*} \lambda \eta \dot{\beta} \beta \omega$ & $\lambda \dot{\eta} \psi о \mu a \iota$ & in compositis & $\chi \omega \rho \eta \dot{\eta} \sigma$, et \\
\hline
\end{tabular}

Alia sunt, quæe utramque Futuri formam vi.Activâ promiscuè usurpant ; ut

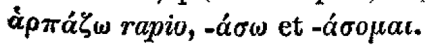


to be found on pp. 105-120 of the book, which listed anomalous (irregular) verbs. Eric Sharwood Smith, later a well-known progressive headmaster, was a pupil at King Edward VI School in Birmingham from 1874 to 1883 , and remembered that 'All these - I shudder as I recall the fact - had to be learned by heart and regularly reproduced when 'up' in class, and woe betide the idle or careless small boy who showed ignorance of them! ... Truly there is something divine in the classical languages, that could survive such handling' (Sharwood Smith, 1948, 112). Such complaints might perhaps have been expected of a book whose author had, in his own words, attempted to make it 'a complete repertory of grammatical facts' (Wordsworth 1866, 50).

In 1884 the Delegates were already looking for a replacement grammar, and in that year asked for specimens from J. B. Allen, author of the Latin grammar published in the Clarendon Press Series. These were apparently not approved, and the Homerist (and Delegate) D. B. Monro was asked to look for an alternative author ${ }^{64}$. In 1894, two years after Wordsworth's death, Monro was deputed to revise both Grammar and Primer for new editions $s^{65}$. He later recalled being able to save five or six pages by cutting out from a long list of irregular verbs those 'which were fictitious, never had existed at all, and were not to be found in any good author whatever': evidently Wordsworth's grammar was even more than a 'complete repertory' (Monro 1905, 69). Neither book reappeared, but after J. B. Allen's death in 1899, Monro revised his Elementary Greek Grammar for publication, and it appeared in 1902.

\section{Conclusion}

The story of Wordsworth's grammar, like that of its author, is a curious mixture of centrality and marginality. For half a century it was in effect what he wanted it to be, a 'national grammar. Adopted by several of the leading public schools in the early 1840 s, it was securely enthroned as a standard textbook when the Clarendon headmasters selected it in 1863. The power of such adoption was evident in the collapse in the sales of its brother-grammar after Kennedy was chosen by the headmasters to assemble a standard Latin primer. The authority of the Greek grammar stemmed originally from the combination of Etonian antiquity and German philology assembled by its author. The book's marginality lay in its being conceived as part of a remarkable and doomed campaign for grammatical and religious uniformity, manifested among other things in its author's resolute adherence to Latin in text and even advertisements. With his brother, Charles Wordsworth pursued a conception of Anglican faith and practice rooted in the seventeenth and eighteenth centuries, ignoring the way in which the nineteenth was moving in new directions: secularism, the vernacular, and a view of pupils as developing selves rather than just receptacles. In the 1830s and 1840s, their campaign was assisted by their positions at Winchester and Harrow and by their powerful church and university connections. In their later years, when they had moved on to higher things, they remained embedded in the upper reaches of the Anglican Church as bishops, while still holding to their extreme high-church views.

The history of the Grammar, as it moved through the early stages with Murray and then, after the traumatic break in 1844 (traumatic for him, but apparently not for Word-

${ }^{64}$ OUP archive, Publishing Committee minutes, 15 June 1886.

${ }^{65}$ OUP archive, Delegates' Order Books, 16 February 1894. 
sworth), with OUP, traverses several periods of both publishing and educational history. The connection between the firm of John Murray and Eton College, mediated in the 1840s by Lockhart and the Quarterly Review, was still in place in the 1880s, when a later John Murray published classical textbooks for Eton by arrangement with the headmaster, Edmond Warre. By then, resistance to the power of the nine Clarendon headmasters had prompted the foundation of the Headmasters' Conference (1869), though this soon came to be dominated by the Clarendon schools. In the 1880s, when after much agonising the HMC commissioned Benjamin Kennedy to produce a revised Latin primer, the question of a Greek textbook was sidelined. But by then Wordsworth's grammar had itself been sidelined by its own offshoot, the Greek Primer, whose publication in 1871 had, as we have seen, been as fatal to sales of its elder brother as Kennedy's 1866 Primer had been to Christopher Wordsworth's Latin grammar.

Wordsworth's Grammar (1839) and Primer (1871): editions and impressions

Figures in italics are estimates, based on payments to the author or other evidence.

Grammar

(John Murray)

$\begin{array}{ll}1839^{1} & 2000 \\ 1840^{2} & 1000 \\ 1841^{3} & 2500 \\ 1841^{4} & 500 \\ 1842^{4} & 4500\end{array}$

(Oxford University Press)

$\begin{array}{ll}1844^{5} & 5000 \\ 1846 & 6000 \\ 1851 & 5000 \\ 1853 & 6000\end{array}$

1874

1875

1876

1877

1878

1879

1880

$1882^{19}$

1883

1884

1885

4000

\section{Primer}

5000

5000

5000

5000

6000

5000

4000

5000

5000 
Grammar

1887

1893

1896

1907

1914

Out of print July 1929

Total 107,000
Primer

8000

3000

3000

1000

2000

Out of print April 1942

Total 79,000

\section{Sources}

Grammar: Copies Ledger D, John Murray Archive, National Library of Scotland, MS. 42729, 243, 271, 305; OUP, Delegates' Order Books; 1882 printing in OUP library, OP 40170.

Primer: Delegates' Order Books; 1919 printing in OUP library, OP 40796.

\section{References}

Bowen, E. E., On teaching by means of grammar, in F. W. Farrar (ed.) Essays on a Liberal Education. London $1867,179-204$.

Brock, W.H. and Meadows, A. J. The Lamp of Learning: Two Centuries of Publishing at Taylor and Francis. London, Taylor and Francis 1998.

Engledow, C. Examination Questions on the Graecae Grammaticae Rudimenta. London, Longmans 1845.

Fearon, W. A. The Passing of Old Winchester. Winchester, Warren 1936.

Lathbury, D. C. Letters on Church and Religion of William Ewart Gladstone. London, J. Murray 1910.

Leach, A. F. History of Winchester College. London, Duckworth 1899.

[Liddell, H. G.] Review of Wordsworth's Greek grammar. Educational Magazine, September 1840, 200-202. Lyte, H. C. M. History of Eton College, 1440-1898. London, J. Murray 1899.

Monro, D. B. Contribution to discussion on simplification of grammars. Proceedings of the Classical Association of England and Wales 2 (1905), 68-70.

Murray, O., The beginnings of Greats II: Ancient History, in M. G. Brock and M. C. Curthoys (eds.), History of the University of Oxford VI: The Nineteenth Century, Part I, Oxford 1997, 520-40.

[Palmer, R.], Greek Grammars for the use of schools, The British Critic, October 1840, 295-334.

Sharwood Smith, E. 'Years of a Pilgrimage', unpublished TS, 1948. Copy in author's possession.

Shrosbree, C. Public Schooling and Private Education: The Clarendon Commission, 1861-64, and the Public School Acts. Manchester, Manchester UP 1988.

Stanley, A. P. Life of Thomas Arnold. London, J. Murray [1844] 1904.

Stray, C. A. Grinders and Grammars: a Mid-Victorian Controversy. Reading, Textbook Colloquium 1995.

Stray, C. A. Classics Transformed: Schools, Universities, and Society in England 1830-1960. Oxford, OUP 1998.

Stray, C. A. Liddell and Scott: myths and markets, in: Id. (ed.) Classical Dictionaries, Past, Present and Future, London, Duckworth, 2010, 94-118.

Stray, C. A. (a), Classics, in: S. Eliot (ed.) History of Oxford University Press III: 1780-1896, Oxford, OUP, 2013, 435-70.

Stray, C. A. (b), 'Educational publishing, in: S. Eliot (ed.) History of Oxford University Press III: 1780-1896, Oxford, OUP, 2013, 472-510.

Sutcliffe, P. The Oxford University Press: An Informal History. Oxford, OUP 1978.

Wordsworth, C. The School Greek Grammar. Edinburgh, Constable 1866.

Wordsworth, C. Annals of My Early Life 1806-1846. London, J. Murray 1891. 
Wordsworth, C. Annals of My Life 1846-1856. London, J. Murray 1893.

Wordsworth, J. The Episcopate of Christopher Wordsworth, Bishop of St Andrews, Dunkeld and Dunblane, 1853-1892. London, Longmans 1899.

For citation: Christopher Stray. A Semi-Sacred Monster: Charles Wordsworth's Graecae Grammaticae Rudimenta (1839). Philologia Classica 2016, 11(1), 98-115. DOI: 10.21638/11701/spbu20.2016.110

\section{ПОЛУСАКРАЛЬНЫЙ МОНСТР: ОСНОВЫ ГРЕЧЕСКОЙ ГРАММАТИКИ (1839) ЧАРЛЬЗА ВОРДСВОРТА}

\section{Кристофер Стрец̆}

Школьная грамматика древнегреческого языка, составленная Ч. Вордсвортом, на протяжении нескольких десятилетий лидировала на британском рынке. Несмотря на ее центральное место в преподавании, необычность грамматики Вордсворта заключалась в том, что она была написана по-латыни, в то время как английский язык становился в школьной практике общепринятым. Книга стала частью эксцентричной кампании, проводимой автором и его братом, с целью составления стандартных грамматик как средства содействия единству религии. В итоге появилась краткая английская версия, которая прекратила продажи изначального варианта книги. В статье рассматривается взаимодействие между идеологией, политикой в сфере образования и экономикой издательской отрасли.

Ключевые слова: грамматика, древнегреческий, религия, экономика издательской отрасли, политика в сфере образования, Джон Мюррей, Oxford University Press, стереотипное издание. 